\title{
Phenol Removal from Water with Potassium Permanganate Modified Granular Activated Carbon
}

\author{
Jin Zhang \\ School of Environmental Science and Engineering, Dalian Maritime University, Dalian, China. \\ Email: zhangjin7986@163.com
}

Received January $29^{\text {th }}, 2013$; revised March $3^{\text {rd }}, 2013$; accepted April $1^{\text {st }}, 2013$

Copyright (C) 2013 Jin Zhang. This is an open access article distributed under the Creative Commons Attribution License, which permits unrestricted use, distribution, and reproduction in any medium, provided the original work is properly cited.

\begin{abstract}
In order to improve adsorption capacity of granular activated carbon (GAC), potassium permanganate was used to react with GAC to change the surface properties and improve the adsorption capacity of GAC. By batch experiments, improvement of adsorption capacity of potassium permanganate modified $\mathrm{GAC}\left(\mathrm{GAC}_{\mathrm{M}}\right)$ was studied. The influence of adsorption time, temperature, ratio of phenol with $\mathrm{GAC} \mathrm{GAC}_{\mathrm{M}}$, initial concentration of phenol and $\mathrm{pH}$ on adsorption efficiency of $\mathrm{GAC}_{\mathrm{M}}$ was studied. The results showed that modified by potassium permanganate, the adsorption capacity of GAC improved to a higher level. The removal efficiency of phenol increased to about $20 \%$.
\end{abstract}

Keywords: Modified Granular Activated Carbon; Potassium Permanganate; Phenol; Adsorption

\section{Introduction}

With the development of chemical industry, more and more organic compounds were disposed into water and aggravated water pollution. Adsorption is an effective technology in removing organic pollutants from water [1-3]. In which the number of adsorbents, activated carbon has be seen as one of the main and effective adsorbents. Activated carbon has high surface area, large pore volume, tunable pore size, chemical stability, high hydrophobicity and interconnected frameworks [4-8]. While, pore structure and surface properties affect the adsorption capacity of activated carbon $[9,10]$. To improve the adsorption efficiency and save dosage, in recent years, many researchers have dedicated on researches of modification of activated carbon [11-18]. The use of oxidizing agents is the most common methodology to modify AC surface [19-22]. Some researchers have found that carboxylic functional groups can be introduced upon oxidizing the surface of carbon materials by various oxidation agents such as concentrated nitric [23], ozone [24], ammonium [25] and $\mathrm{H}_{2} \mathrm{O}_{2}$ [26], which could help to change the inert and hydrophobic nature of carbon materials and enhance the wettability for polar solvents and make the surface active for the immobilization of organic compounds via adsorption [27]. For example, Gil et al. [28] studied the oxidation of $\mathrm{HNO}_{3}$ and found that under different temperature, oxidation of $\mathrm{HNO}_{3}$ would affect the macro and micro porous structure of activated carbon. Liu et al. [7] found that modification of air oxidation improved the wettability and the adsorption properties of pitch-based spherical activated carbon as the increase of the oxygen-containing groups. Yin et al. [29] reviewed the chemical, physical and biological modification techniques of activated carbon, and found that the beneficial effects of specific modification techniques on activated carbon adsorption of targeted contaminant species from aqueous solutions were profound. Utrilla et al. [18] compared the advantages and disadvantages of different methodologies to modify the surface of activated carbons and found that modified by using $\mathrm{H}_{2} \mathrm{O}_{2}, \mathrm{O}_{3}$ and $\mathrm{HNO}_{3}$, acidic surface functional groups increase in the $\mathrm{AC}$ surface as the reduce of the AC surface area; and the nitrogenation or sulfuration of the AC surface can increase its basicity favoring the adsorption of organic compounds.

As an oxidant, potassium permanganate has been widely used in water treatment [30-35]. In this paper, activated carbon was modify with potassium permanganate, and with representative organic matter of phenol, the impact of modification on adsorption capacity of activated carbon was studied.

\section{Materials and Methods}

\subsection{Pretreatment of Granular Activated Carbon}

The particle size of granular activated carbon was 10 - 20 
mish. After repeatedly soaked and washed with deionized water, the activated carbon was dried to constant weight at $105^{\circ} \mathrm{C}$ for over $24 \mathrm{~h}$.

\subsection{Modification Method of Activated Carbon}

Modification of GAC was conducted under neutral condition. The activated carbon was immersed in pollution of potassium permanganate (controlled the ratio of concentration of potassium permanganate to activated carbon (L/M) to a certain value) for a certain period of time and slow stirring with constant temperature oscillator, then separated and washed repeatedly with deionized water to no color, then dried to constant weight at $105^{\circ} \mathrm{C}$ for $24 \mathrm{~h}$.

\subsection{Adsorption Studies}

Adsorption experiments were performed to study the effects of important parameters such as effect of temperature, amount of adsorbent, time of contact and $\mathrm{pH}$, ratio of phenol with $\mathrm{GAC} / \mathrm{GAC}_{\mathrm{M}}$, initial concentration of phenol in water was $250 \mathrm{mg} / \mathrm{L}$. $250 \mathrm{ml}$ of water (contaminated with phenol) was taken into $500 \mathrm{ml}$ volumetric flask, then $2 \mathrm{~g}$ of adsorbents $\left(\mathrm{GAC} / \mathrm{GAC}_{\mathrm{M}}\right)$ was put into the flasks. The flask was then subjected to shaking for proper adsorption on magnetic stirrer for a certain time. After the fixed time of contact, these solutions were filtered with filter (whatman filter size $0.45 \mu \mathrm{m}$ PES filter media ) and the amount of the phenol adsorbed was analyzed.

\subsection{Analytic Methods}

The concentration of phenol was analyzed with liquid chromatography. The chromatography column was Century SILC $^{18}$-EPS $(200 \times 4.6 \mathrm{~mm}, 5 \mu \mathrm{m})$, made in Germany. The mobile phase was acetonitrile $50 \%$-water $50 \%$ of volume proportion. Column temperature was $20^{\circ} \mathrm{C}$, and column pressure was $11.0 \mathrm{MPa}$. The flow rate of mobile phase was $1.0 \mathrm{~mL} / \mathrm{min}$. The detector was UV detector, and with detection wavelength of $270 \mathrm{~nm}$.

\section{Results and Discussion}

\subsection{Effect of Potassium Permanganate Concentration on Adsorption Efficiency of $\mathbf{G A C}_{\mathbf{M}}$}

2 g GAC was modified with $20 \mathrm{~mL}$ different concentration of Potassium permanganate solution of 10.0, 15.0, $20.0,25.0,30.0,40.0,50.0,60.0 \mathrm{mg} / \mathrm{L}$ for $90 \mathrm{~min}$ previously. The initial phenol concentration was $250 \mathrm{mg} / \mathrm{L}$. The adsorption time of $\mathrm{GAC}_{\mathrm{M}}$ for phenol was controlled for $4 \mathrm{~h}$. Temperature was $20^{\circ} \mathrm{C}$. Effect of potassium permanganate concentration on adsorption efficiency of
$\mathrm{GAC}_{\mathrm{M}}$ for phenol was shown in Figure 1.

It could be seen that modified with different concentration of potassium permanganate, the adsorption efficiency of $\mathrm{GAC}_{\mathrm{M}}$ for phenol differed. At begging, the removal efficiency of phenol increased with the increase of concentration of potassium permanganate. When concentration of potassium permanganate increased to 30 $\mathrm{mg} / \mathrm{L}$, the removal efficiency of phenol increased to the highest, and then decreased with the increase of concentration of potassium permanganate.

This could be because that with the increase of concentration of potassium permanganate, there are more and more potassium permanganate react with GAC and oxidized the surface of GAC, and formed more pore structure and functional groups in GAC surface, which would increase the adsorption capacity for phenol. But when concentration of potassium permanganate increased to a higher level, excessive potassium permanganate would react with the surface function groups, which would decrease the adsorption capacity of activated carbon otherwise.

From results of Figure 1, it could be concluded that for $2 \mathrm{~g} \mathrm{GAC}$, the optimum concentration of potassium permanganate was $30 \mathrm{mg} / \mathrm{L}$.

\subsection{Effect of Modification Time on Adsorption Efficiency of GAC $_{M}$}

In process of modification, the concentration of potassium permanganate solution was 30 and $40 \mathrm{mg} / \mathrm{L}$, and the dosage of GAC was $2.0 \mathrm{~g}$. Modification time of GAC with potassium permanganate was controlled at 10, 30, $60,90,120,150,180,210 \mathrm{~min}$ respectively.

The adsorption experiment was conducted in $250 \mathrm{~mL}$

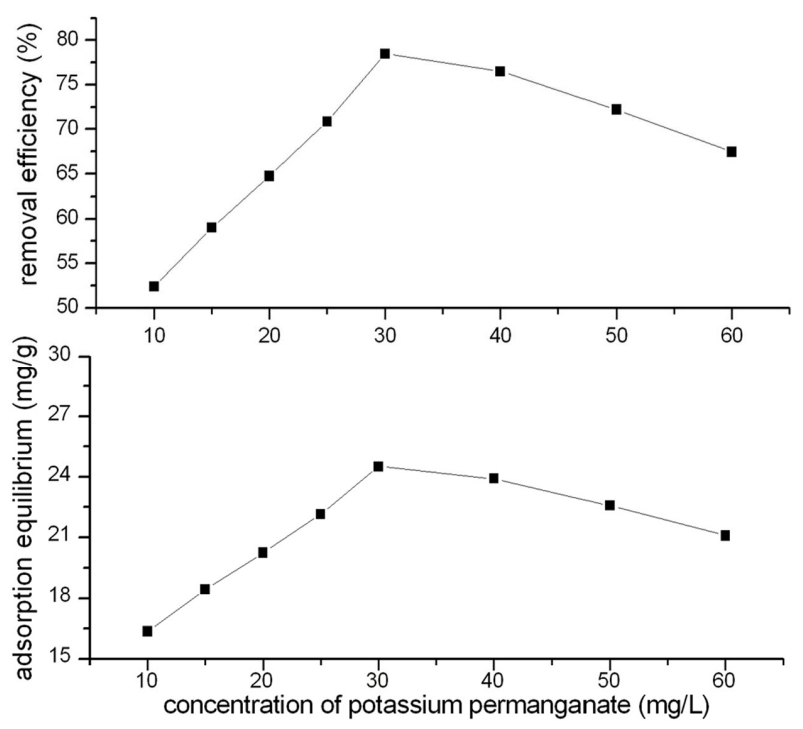

Figure 1. Effect of concentration of potassium permanganate on adsorption capacity of $\mathrm{GAC}_{\mathrm{M}}$. 
water. Temperature was $20^{\circ} \mathrm{C}$. The phenol concentration was $250 \mathrm{mg} / \mathrm{L}$, and the dosage of GACM was $2.0 \mathrm{~g}$ (that is the ratio of phenol with $\mathrm{GAC}_{\mathrm{M}}$ was $62.5: 2.0 \mathrm{mg} / \mathrm{g}$ ), and adsorption time was 4 h. Figure 2 showed the effect of modified time on adsorption capacity for phenol of $\mathrm{GAC}_{\mathrm{M}}$.

It could be seen that the removal efficiency for phenol increased with the increase of modification time of $\mathrm{GAC}_{\mathrm{M}}$. At beginning, the removal rate increased very fast, and when modification time increased to $90 \mathrm{~min}$, the removal rate increased gentle. At the same time, it could be seen that when concentration of potassium permanganate was $30 \mathrm{mg} / \mathrm{L}$, the removal efficiency of phenol was higher than that of $40 \mathrm{mg} / \mathrm{L}$. So on later, for $2.0 \mathrm{~g}$ $\mathrm{GAC}$, the concentration of potassium permanganate was controlled at $30 \mathrm{mg} / \mathrm{L}$, and the modification time was 90 $\min$.

\subsection{Effect of Time on Adsorption Capacity of GAC/GAC $_{M}$}

Temperature is $20^{\circ} \mathrm{C}$. Ratio of phenol with $\mathrm{GAC} / \mathrm{GAC}_{\mathrm{M}}$ was $62.5: 2.0 \mathrm{mg} / \mathrm{g}$. Results of adsorption capacity versus time were shown in Figure 3.

It could be seen that for $\mathrm{GAC}$ and $\mathrm{GAC}_{\mathrm{M}}$, the adsorption capacity for phenol increased with the increase of adsorption time to about 4 hours, and then were nearly at constant. This showed that the adsorption for phenol of $\mathrm{GAC}_{\mathrm{GAC}}$ was reached equilibrium at nearly 4 hours. At the same time, it could be seen that the equilibrium of $\mathrm{GAC}_{\mathrm{M}}$ was about $28 \mathrm{mg} / \mathrm{g}$, while of GAC was $20 \mathrm{mg} / \mathrm{g}$. This showed that the adsorption capacity for phenol of $\mathrm{GAC}_{\mathrm{M}}$ was greater than that of GAC.

\subsection{Effect of Temperature}

The temperature was adjusted to $20^{\circ} \mathrm{C}, 25^{\circ} \mathrm{C}$ and $30^{\circ} \mathrm{C}$ re-
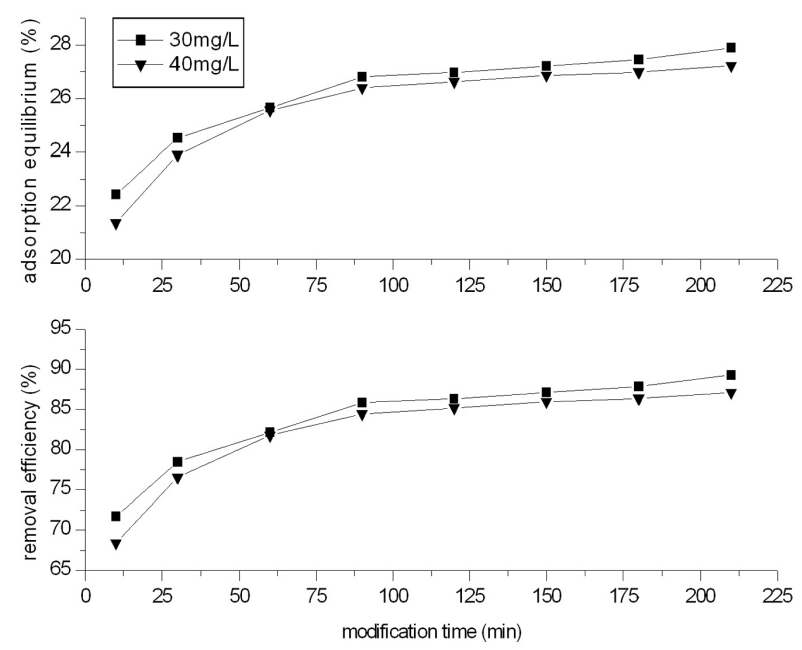

Figure 2. Effect of modification time of GAC on phenol removal rate by $\mathrm{GAC}_{\mathrm{M}}$.

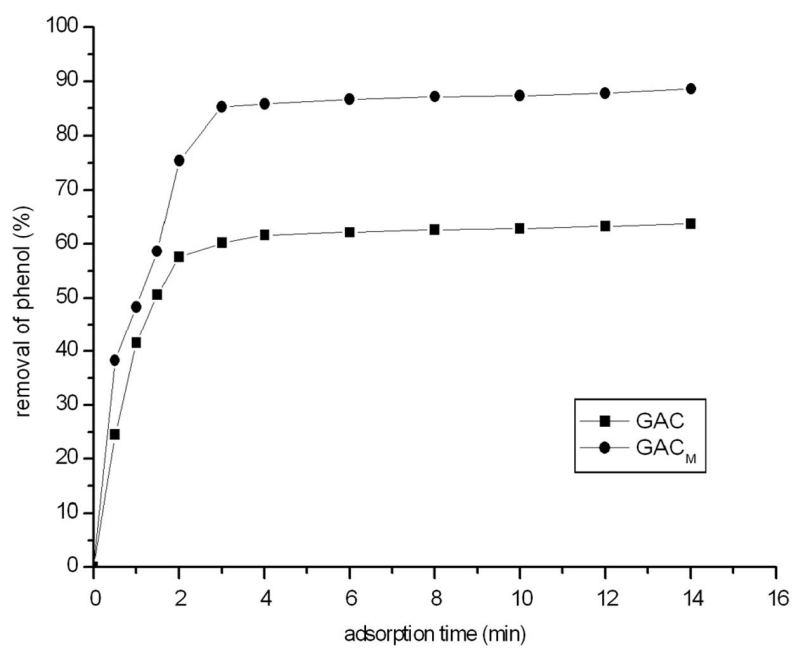

Figure 3. Effect of adsorption time.

spectively. In $250 \mathrm{~mL}$ water, the dosage of $\mathrm{GAC} / \mathrm{GAC}_{\mathrm{M}}$ was $2.0 \mathrm{~g}$, and the concentration of phenol was adjusted to $50,100,150,200,250,300,350,400 \mathrm{mg} / \mathrm{L}$ to satisfied the ratio of phenol to $\mathrm{GAC}_{\mathrm{GAC}}$ was $12.5: 2.0,25.0: 2.0$, 37.5:2.0, 50.0:2.0, 62.5:2.0, 75.0:2.0, 87.5:2.0, 100.0:2.0 $\mathrm{mg} / \mathrm{g}$. Adsorption time was $4 \mathrm{~h}$. The effect of temperature on removal of phenol at different ratio of phenol to $\mathrm{GAC}_{\mathrm{GAC}}$ was shown in Figure 4.

The results showed that the removal efficiency for phenol decreased with the increase of temperature. When temperature increased from $20^{\circ} \mathrm{C}$ to $30^{\circ} \mathrm{C}$, the highest removal efficiency for phenol decreased to $50.86 \%$ from $61.47 \%$ with GAC, and decreased from $78.46 \%$ to $61.02 \%$ with $\mathrm{GAC}_{\mathrm{M}}$. That is to say that the adsorption for phenol with $\mathrm{GAC} / \mathrm{GAC}_{\mathrm{M}}$ is exothermic, and the lower temperature is favorable for adsorption for phenol by $\mathrm{GAC} / \mathrm{GAC}_{\mathrm{M}}$.

At the same time, it could be seen that the effect of temperature on adsorption for phenol with $\mathrm{GAC}_{\mathrm{M}}$ was as the same as that with GAC, but at same temperature, the adsorption capacity of $\mathrm{GAC}_{\mathrm{M}}$ was higher. On later experiments, temperature was $20^{\circ} \mathrm{C}$.

\subsection{Effect of Dosage of Activated Carbon on Adsorption Capacity}

The concentration of phenol in water was $250 \mathrm{mg} / \mathrm{L}$, and the dosage of $\mathrm{GAC} / \mathrm{GAC}_{\mathrm{M}}$ was adjusted to satisfy the ratio of phenol to $\mathrm{GAC} \mathrm{GAC}_{\mathrm{M}}$ was $62.5: 0.5,62.5: 1.0$, $62.5: 1.5,62.5: 2.0,62.5: 2.5,62.5: 3.0,62.5: 3.5,62.5: 4.0$ $\mathrm{mg} / \mathrm{g}$. Previous modification time of $\mathrm{GAC}_{\mathrm{M}}$ was 30 and $90 \mathrm{~min}$ respectively. Adsorption time was $4 \mathrm{~h}$. Result of Figure 5 showed the effect of dosage of $\mathrm{GAC} / \mathrm{GAC}_{\mathrm{M}}$ on removal efficiency for phenol from water by adsorption of $\mathrm{GAC} / \mathrm{GAC}_{\mathrm{M}}$.

It could be seen that at the same initial concentration of phenol, the removal efficiency for phenol increased 


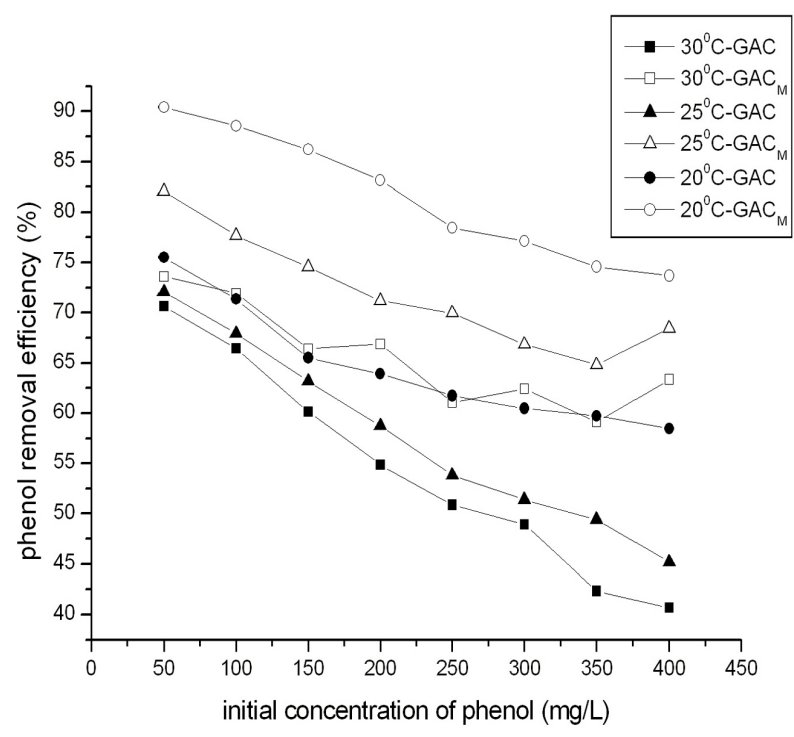

Figure 4. Effect of temperature on the adsorption rate for phenol by GAC/GAC .

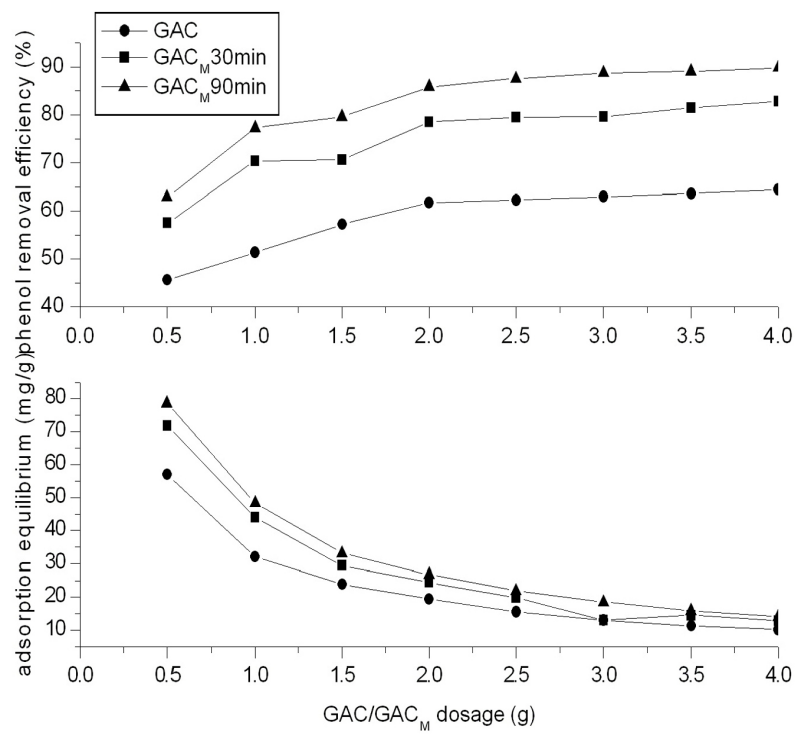

Figure 5. Effects of dosage of carbon on the removal rate.

with the increase of $\mathrm{GAC} / \mathrm{GAC}_{\mathrm{M}}$ dosage. That is to say that when dosage of activated carbon was insufficient, the adsorption of activated carbon reached saturation easily, and the removal efficiency of phenol was low. With the increase of dosage of activated carbon, the removal efficiency of phenol increased. When dosage of activated carbon was smaller than $2.0 \mathrm{~g}$, the removal rate for phenol increased fast with the increase of $\mathrm{GAC} /$ $\mathrm{GAC}_{\mathrm{M}}$ dosage. While when dosage of activated carbon was larger than $2.0 \mathrm{~g}$, the removal rate for phenol increased slowly, and at that time, the equilibrium adsorption capacity was lower. This is because that when dosage of activated carbon was sufficient, the phenol was removed all the nearly. Increase of activated carbon would increase the costs. Therefore, the dosage of activated carbon should be appropriate.

From results of Figure 5, it also could be seen that the optimum dosage of activated carbon has nothing to do with modification or not. At experiment condition, the optimal ratio of phenol to activated carbon was 62.5:2.0 $\mathrm{mg} / \mathrm{g}$. At the same time, the adsorption capacity of $\mathrm{GAC}_{M}$ was higher significantly than that of GAC. For example, the removal efficient for phenol with $\mathrm{GAC}_{\mathrm{M}}$, at ratio of phenol to activated carbon was $62.5: 1.2 \mathrm{mg} / \mathrm{g}$, was higher than that of GAC at ratio of $62.5: 4.0 \mathrm{mg} / \mathrm{g}$.

At the same time, modification time influence the removal efficiency for phenol by $\mathrm{GAC}_{\mathrm{M}}$. With modification time increased to $90 \mathrm{~min}$ from $30 \mathrm{~min}$, the removal efficiency for phenol increased to a higher level.

\subsection{Effect of Initial Concentration of Phenol on Removal Efficiency}

Adsorption time was 4 hour. The GAC was modified by potassium permanganate pollution of $30 \mathrm{mg} / \mathrm{L}$, temperature was $20^{\circ} \mathrm{C}$. Dosage of $\mathrm{GAC} \mathrm{GAC}_{\mathrm{M}}$ was $2.0 \mathrm{~g}$, and the concentration of phenol in water was adjusted to satisfy the ratio of phenol to $\mathrm{GAC} / \mathrm{GAC}_{\mathrm{M}}$ was $12.5: 2.0$, 25.0:2.0, 37.5:2.0, 50.0:2.0, 62.5:2.0, 75.0:2.0, 87.5:2.0, $100.0: 2.0 \mathrm{mg} / \mathrm{g}$ respectively.

Results in Figure 6 showed the effect of initial concentration of phenol on removal of phenol by adsorption of $\mathrm{GAC} / \mathrm{GAC}_{\mathrm{M}}$. It could be seen that with the increase of initial concentration of phenol, the equilibrium adsorption amount of phenol increased, while the removal efficiency of phenol decreased.

This is because that at a certain dosage of GAC, more and more phenol was absorbed by GAC, so the equilibrium adsorption amount of phenol increased with the
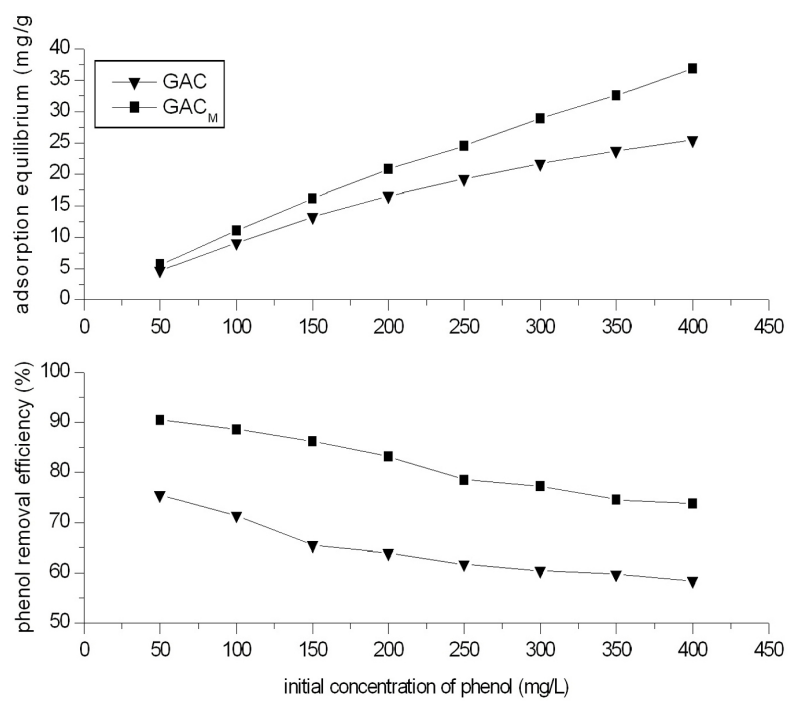

Figure 6. The effects of initial concentration of phenol the removal rate. 
increase of initial concentration of phenol. On the other hand, the saturated adsorption capacity of GAC is limited. When the initial concentration of phenol is high, the phenol can't be absorbed by GAC completely, so the removal efficiency of phenol decreased instead. So, at a certain dosage of GAC, the most suitable initial concentration of phenol should be determined by removal efficiency of phenol not equilibrium adsorption amount only. At the same time, it could also be seen that compared with that of GAC, the removal efficiency and equilibrium adsorption amount of phenol by $\mathrm{GAC}_{\mathrm{M}}$ increased to a high level.

\subsection{Effect of $\mathbf{p H}$}

Temperature was $20^{\circ} \mathrm{C}$, phenol concentration in water was $250 \mathrm{mg} / \mathrm{L}$, and the dosage of $\mathrm{GAC} \mathrm{GAC}_{\mathrm{M}}$ was $2.0 \mathrm{~g}$ (ratio of phenol to $\mathrm{GAC} \mathrm{GAC}_{\mathrm{M}}$ was $62.5: 2.0 \mathrm{mg} / \mathrm{g}$ ). Results of Figure 7 show the effect of $\mathrm{pH}$ on adsorption efficiency of phenol by $\mathrm{GAC}_{\mathrm{GAC}}$. It could be seen that in acidic and neutral condition, the removal efficiency is high. When $\mathrm{pH}$ value is in range of $3 \sim 6, \mathrm{pH}$ has no effect on removal of phenol by GAC and $\mathrm{GAC}_{\mathrm{M}}$. While with the increase of $\mathrm{pH}$ from 6 to 9 , the removal efficiency of phenol decreased to about $30 \%$, and the equilibrium adsorption amount decreased about $10 \mathrm{mg} / \mathrm{g}$. This may be because that when $\mathrm{pH}$ is less than 7 , phenol exists mainly in molecular form, which is slightly soluble in water, and easily be absorbed by GAC. While when $\mathrm{pH}$ is bigger than 7, phenol exists in ion form, which is soluble in water and is difficult be absorbed by GAC.

This result also showed that the removal efficiency of phenol by adsorption of GAC is obviously superior to phenol salt.

Compared with $\mathrm{GAC}, \mathrm{GAC}_{\mathrm{M}}$ is superior for removal

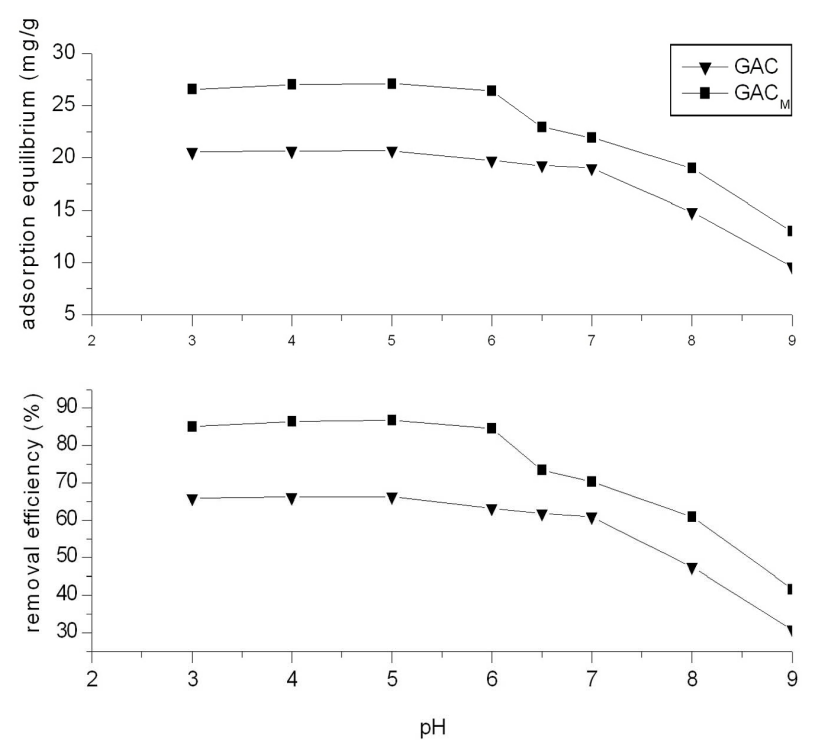

Figure 7. Effects of $\mathrm{pH}$ on the removal rate. of phenol. The removal efficiency increased about $25 \%$, and the equilibrium increased about $7 \mathrm{mg} / \mathrm{g}$.

\section{Conclusions}

In order to improve adsorption properties of GAC, modification for GAC was inducted by solution of potassium permanganate. By batch experiment, the removal efficiency of phenol by modified granular activated carbon was studied. The results show that:

1) Modification with potassium permanganate improved the adsorption capacity of GAC. Compared with GAC, the adsorption efficiency of Phenol with $\mathrm{GAC}_{\mathrm{M}}$ increased $20 \%$.

2) The adsorption equilibrium time of $\mathrm{GAC}_{\mathrm{M}}$ is about $4 \mathrm{~h}$, as same as that of GAC. For $2.0 \mathrm{~g} \mathrm{GAC}$, the optimum concentration of potassium permanganate was $30 \mathrm{mg} / \mathrm{L}$, and modification time was $90 \mathrm{~min}$.

3) The adsorption of $\mathrm{GAC} / \mathrm{GAC}_{\mathrm{M}}$ is exothermic reaction. Modification affects the adsorption efficiency of GAC, but don't affect the influence of temperature.

4) The adsorption property of $\mathrm{GAC}_{M}$ was better in acidic and neutral than in alkaline condition.

5) The ratio of phenol to $\mathrm{GAC} / \mathrm{GAC}_{\mathrm{M}}$ affects the adsorption efficiency of phenol with $\mathrm{GAC} / \mathrm{GAC}_{\mathrm{M}}$. The optimum ratio of phenol to $\mathrm{GAC}_{\mathrm{GAC}}$ was about 62.5:2.0 $\mathrm{mg} / \mathrm{g}$.

\section{Acknowledgements}

J. Z. thanks to the supported of "Natural Science Foundation of Liaoning Province of Grant No. 2011010158" and "the Fundamental Research Funds for the Central Universities No. 3132013083".

\section{REFERENCES}

[1] T. Yamamoto, S. I. Kim, J. Chaichanawong, E. Apiluck and T. Ohmori, "Removal of Aqueous Organic Pollutants by Adsorption-Catalytic Process Using Mesoporous Carbon Beads Loaded with Metal Oxides," Applied Catalysis B: Environmental, Vol. 88, No. 3-4, 2009, pp. 455-461. doi:10.1016/j.apcatb.2008.10.011

[2] A. Jasper, H. H. Salih, G. A. Sorial, R. Sinha, R. Krishnan and C. L. Patterson, "Impact of Nanoparticles and Natural Organic Matter on the Removal of Organic Pollutants by Activated Carbon Adsorption," Environmental Engineering Science, Vol. 27, No. 1, 2010, pp. 85-93. doi:10.1089/ees.2009.0234

[3] G. A. Sorial, M. T. Suidan, R. D. Vidic and R. C. Brenner, "Effect of GAC Characteristics on Adsorption of Organic Pollutants," Water Environment Research, Vol. 65, No.1, 1993, pp. 53-57. doi:10.2175/WER.65.1.7

[4] J. Jaramillo, P. M. Álvarez and V. G. Serrano, "Oxidation of Activated Carbon by Dry and Wet Methods Surface Chemistry and Textural Modifications," Fuel Processing Technology, Vol. 91, No. 11, 2010, pp. 1768-1775. 
doi:10.1016/j.fuproc.2010.07.018

[5] H. Oda, A. Yamashita, S. Minoura, M. Okamoto and T. Morimoto, "Modification of the Oxygen-Containing Functional Group on Activated Carbon Fiber in Electrodes of an Electric Double-Layer Capacitor," Journal of Power Sources, Vol. 158, No. 2, 2006, pp. 1510-1516. doi:10.1016/j.jpowsour.2005.10.061

[6] M. G. Alves, M. M. Sabio and F. R. Reinoso, "Modification of Activated Carbon Hydrophobicity by Pyrolysis of Propene," Journal of Analytical and Applied Pyrolysis, Vol. 89, No. 1, 2010, pp. 17-21. doi:10.1016/j.jaap.2010.04.009

[7] C. J. Liu, X. Y. Liang, X. J. Liu, Q. Wang, N. Teng, L. Zhan, R. Zhang, W. M. Qiao and L. C. Ling, "Wettability Modification of Pitch-Based Spherical Activated Carbon by Air Oxidation and Its Effects on Phenol Adsorption," Applied Surface Science, Vol. 254, No. 9, 2008, pp. 26592665. doi:10.1016/i.apsusc.2007.10.026

[8] J. Aguado, J. M. Escola and M. C. Castro, "Influence of the Thermal Treatment upon the Textural Properties of Sol-Gel Mesoporous $\gamma$-Alumina Synthesized with Cationic Surfactants," Microporous Mesoporous Mater, Vol. 128, No. 1-3, 2010, pp. 48-55. doi:10.1016/j.micromeso.2009.08.002

[9] J. S. Im, M. J. Jung and Y. S. Lee, "Effects of Fluorination Modification on Pore Size Controlled Electrospun Activated Carbon Fibers for High Capacity Methane Storage," Journal of Colloid and Interface Science, Vol. 339, No. 1, 2009, pp. 31-35. doi:10.1016/i.jcis.2009.07.013

[10] Y. W. Lee, J. W. Park, S. J. Jun, D. K. Choi and J. E. Yie, "NOx Adsorption-Temperature Programmed Desorption and Surface Molecular Ions Distribution by Activated Carbon with Chemical Modification," Carbon, Vol. 42, No. 1, 2004, pp. 59-69. doi:10.1016/j.carbon.2003.09.019

[11] S. B. Lyubchik, R. Benoit and F. Beguin, "Influence of Chemical Modification of Anthracite on the Porosity of the Resulting Activated Carbons," Carbon, Vol. 40, No. 8, 2002, pp. 1287-1294. doi:10.1016/S0008-6223(01)00288-3

[12] R. Berenguer, J. P. M. Lozar, C. Quijada, D. C. Amoros and E. Morallon, "Effect of Electrochemical Treatments on the Surface Chemistry of Activated Carbon," Carbon, Vol. 47, No. 4, 2009, pp. 1018-1027. doi:10.1016/j.carbon.2008.12.022

[13] B. P. Bakhmatyuk, B. Y. Venhryn, I. I. Grygorchak and M. M. Micov, "Influence of Chemical Modification of Activated Carbon Surface on Characteristics of Supercapacitors," Journal of Power Sources, Vol. 180, No. 2, 2008, pp. 890-895. doi:10.1016/j.jpowsour.2008.02.045

[14] D. Q. Mo and D. Q. Ye, "Surface Study of Composite Photocatalyst Based on Plasma Modified Activated Carbon Fibers with $\mathrm{TiO}_{2}$," Surface \& Coatings Technology, Vol. 203, No. 9, 2009, pp. 1154-1160. doi:10.1016/j.surfcoat.2008.10.007

[15] B. Z. Li, Z. P. Lei, X. H. Zhang and Z. G. Huang, "Adsorption of Simple Aromatics from Aqueous Solutions on Modified Activated Carbon Fibers," Catalysis Today, Vol. 158, No. 3, 2010, pp. 515-520. doi:10.1016/j.cattod.2010.08.014

[16] Q. S. Liu, T. Zheng, N. Li, P. Wang and A. Gulizhaer, "Modification of Bamboo-Based Activated Carbon Using Microwave Radiation and Its Effects on the Adsorption of Methylene Blue," Applied Surface Science, Vol. 256, No. 10, 2010, pp. 3309-3315.

doi:10.1016/j.apsusc.2009.12.025

[17] M. J. Jung, E. Jeong, J. W. Lim, S. I. Lee and Y. S. Lee, "Physico-Chemical Surface Modification of activated Carbon by Oxyfluorination and Its Electrochemical Characterization," Colloids and Surfaces A: Physicochemical and Engineering Aspects, Vol. 389, No. 1, 2011, pp. 274 280. doi:10.1016/j.colsurfa.2011.08.013

[18] J. R. Utrilla, M. S. Polo, V. G. Serrano, P. M. Alvarez, M. C. M. A. Ferraz and J. M. Dias, "Activated Carbon Modifications to Enhance Its Water Treatment Applications. An Overview," Journal of Hazardous Materials, Vol. 187, No. 1, 2011, pp. 1-23. doi:10.1016/j.jhazmat.2011.01.033

[19] D. A. Kunkel, E. T. Gall, J. A. Siegel, A. Novoselac, G. C. Morrison and R. L. Corsi, "Passive Reduction of human Exposure to Indoor Ozone," Building and Environment, Vol. 45, No. 2, 2010, pp. 445-452. doi:10.1016/j.buildenv.2009.06.024

[20] F. Cataldo, "Ozone Reaction with Carbon Nanostructures 2: The Reaction of Ozone with Milled Graphite and Different Carbon Black Grades," Journal of Nanoscience and Nanotechnology, Vol. 7, No. 4-5, 2007, pp. 14461454. doi:10.1166/jnn.2007.327

[21] G. P. Khokhlova and S. A. Semenova, "Ozonation of Fibrous Carbon Materials and the Effect of Molybdenum Compounds on This Process," Solid Fuel Chemistry, Vol. 42, No. 1, 2008, pp. 54-59.

[22] J. Jaramillo, V. G. Serrano and P. M. Alvarez, "Enhanced Adsorption of Metal Ions onto Functionalized Granular ACs Prepared from Cherry Stones," Journal of Hazardous Materials, Vol. 161, No. 2-3, 2009, pp. 670-676. doi:10.1016/j.jhazmat.2008.04.009

[23] G. G. Stavropoulos, P. Samaras and G. P. Sakellaropoulos, "Effects of Activated Carbon Modification on Porosity, Surface Structure and Phenol Adsorption," Journal of Hazardous Materials, Vol. 151, No. 2-3, 2008, pp. 414-421. doi:10.1016/j.jhazmat.2007.06.005

[24] J. Jaramilloa, P. M. A. Lvareza and V. G. M. Serrano, "Preparation and Ozone-Surface Modification of Activated Carbon. Thermal Stability of Oxygen Surface Groups," Applied Surface Science, Vol. 256, No. 17, 2010, pp. 52325236. doi:10.1016/j.apsusc.2009.12.109

[25] M. S. Shafeeyan, W. M. A. W. Daud, A. Houshmand and A. A. Niya, "Ammonia Modification of Activated Carbon to Enhance Carbon Dioxide Adsorption: Effect of PreOxidation," Applied Surface Science, Vol. 257, No. 9, 2011, pp. 3936-3942. doi:10.1016/i.apsusc.2010.11.127

[26] X. Song, H. Liu, L. Cheng and Y. Qu, "Surface Modification of Coconut-Based Activated Carbon by LiquidPhase Oxidation and Its Effects on Lead Ion Adsorption," Desalination, Vol. 255, No. 1, 2010, pp. 78-83. doi:10.1016/j.desal.2010.01.011

[27] Z. X. Wu, P. A. Webley and D. Y. Zhao, "Comprehensive Study of Pore Evolution, Mesostructural Stability, and 
Simultaneous Surface Functionalization of Ordered Mesoporous Carbon (FDU-15) by Wet Oxidation as a Promising Adsorbent," Langnuir, Vol. 26, No. 12, 2010, pp. 1027710286. doi: $10.1021 / 1 \mathrm{a} 100455 \mathrm{w}$

[28] A. Gil, G. L. Puenti and P. Grange, "Evidence of Textural Modifications of an Activated Carbon on Liquidphase Oxidation-Treatments," Microporous Materials, Vol. 12, No. 1-3, 1997, pp. 51-61. doi:10.1016/S0927-6513(97)00057-6

[29] C. Y. Yin, M. K. Aroua and W. M. A. W. Daud, "Riview of Modifications of Activated Carbon for Enhancing Contaminant Uptakes from Aqueous Solutions," Separation and Purification Technology, Vol. 52, No. 3, 2007, pp. 403-415. doi:10.1016/j.seppur.2006.06.009

[30] R. B. Mathur, J. Mittal, O. P. Bahl and N. K. Sandle, "Characteristics of $\mathrm{KMnO}_{4}$-Modified PAN Fibres-Its Influence on the Resulting Carbon Fibres' Properties," Carbon, Vol. 32, No. 1, 1994, pp. 71-77. doi:10.1016/0008-6223(94)90010-8

[31] S. Sabrina and G. Francesca, "Conventional Oxidation Treatments for the Removal of Arsenic with Chlorine Dioxide, Hypochlorite, Potassium Permanganate and Mono- chloramine," Water Research, Vol. 44, No. 19, 2010, pp. 5653-5659. doi:10.1016/j.watres.2010.06.032

[32] S. Wilkinson, "Aquaculture Fundamentals: The Use of Lime, Gypsum, Alum and Potassium Permanganate in Water Quality Management," Aquaculture Asia, Vol. 7, No. 2, 2002, pp. 12-13.

[33] L. H. Hu, A. M. Stemig, K. H. Wammer and T. J. Strathmann, "Oxidation of Antibiotics during Water Treatment with Potassium Permanganate: Reaction Pathways and Deactivation," Environmental Science and Technology, Vol. 45, No. 8, 2011, pp. 3635-3642. doi:10.1021/es104234m

[34] L. H. Hu, H. M. Martin and T. J. Strathmann, "Oxidation Kinetics of Antibiotics during Water Treatment with Potassium Permanganate," Environmental Science and Technology, Vol. 44, No. 16, 2010, pp. 6416-6422. doi:10.1021/es101331j

[35] G. T. Li and Y. M. Ying, "Treatment of Pharmaceutical Wastewater by Potassium Permanganate," Advanced Materials Research, Vol. 219-220, 2011, pp. 36-39. doi:10.4028/www.scientific.net/AMR.219-220.36 